\title{
Open repair of a symptomatic popliteal artery aneurysm in a 71-year-old patient: Case report
}

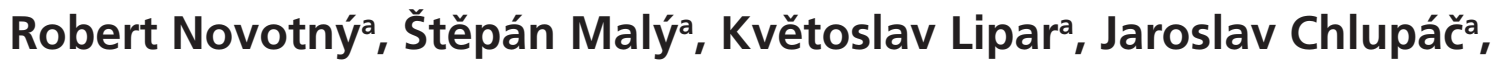 \\ Libor Janoušek ${ }^{a, c}$, Jiří Froněk ${ }^{a, b}$
}

a Transplantation Surgery Department, Institute for Clinical and Experimental Medicine, Prague

b 2nd Faculty of Medicine, Charles University, Prague

c 1st Faculty of Medicine, Charles University, Prague

\section{ARTICLE INFO}

Article history:

Received: 7. 2. 2018

Received in revised form: 1. 3. 2018

Accepted: 2. 3. 2018

Available online: 23. 9. 2019

\section{Klíčová slova:}

Aneurysma

Popliteální tepna

Resekce

Revaskularizace
SOUHRN

Úvod: Nejčastějším místem pro tvorbu aneurysmatu periferní tepny je popliteální tepna (PA). Klinické projevy aneurysmatu popliteální tepny (PAA) sahají od zjištění asymptomatické pulsatilní popliteální rezistence při rutinním fyzikálním vyšetření až po akutní ischemii ohrožující končetiny.

Prezentace př́padu: Představujeme případ 71letého pacienta se $100 \mathrm{~m}$ klaudikačním intervalem na levé dolní končetině, s hmatnou pulsujicí rezistencí v levé podkolenní jamce. Na základě výsledků CT angiografie bylo diagnostikováno aneurysma proximální popliteální tepny. Pro resekci aneurysmatu byl použit dorzální přístup. Aneurysma bylo pečlivě vypreparováno mezi svaly $\mathrm{m}$. semimembranosus a $\mathrm{m}$. biceps femoris. Cévní svorky byly umístěny nad proximální PAA na distální arteria femoralis superficialis (DSFA) a na popliteální tepnu mezi segmenty PA1-PA2. Aneurysma bylo odstraněno a byla provedena chirurgická revaskularizace $\mathrm{s}$ konečnou anastomózou na DSFA a proximální PA pomocí vaskulární protézy $7 \mathrm{~mm}$ polyethylentereftalátu. Pacient byl propuštěn třetí pooperační den bez jakýchkoli komplikací s průchodnou cévní rekonstrukcí a hmatatelnými periferními pulsacemi. Pacient zůstává s průchodnou cévní rekonstrukcí čtyři měsíce po operaci bez ultrasonografických známek stenózy.

Závěr: Otevřená chirurgická resekce zůstává zlatým standardem v léčbě PAA s lepšími dlouhodobými výsledky než endovaskulární techniky. Nové endovaskulární techniky se však stávají sofistikovanějšími, což nám umožňuje používat tyto endovaskulární modality jako alternativní možnost léčby u vybraných pacientů

(c) 2019, ČKS.
Keywords:

Aneurysm

Popliteal artery

Resection

Revascularisation surgery

\begin{abstract}
Introduction: The most frequent site for true peripheral artery aneurysm formation is the popliteal artery (PA). The clinical presentation of popliteal artery aneurysm (PAA) ranges from the finding of an asymptomatic pulsatile popliteal mass on routine physical examination to acute limb-threatening ischaemia.

Case presentation: We are presenting a case of a 71-year-old male patient with $100 \mathrm{~m}$ claudication interval on the left lower extremity, with a palpable pulsating circular resistance in the left popliteal fossa. Based on $\mathrm{CT}$ angiography results, the patient was diagnosed with a proximal popliteal artery aneurysm. A posterior approach was used for the dissection of the aneurysm. The aneurysm was carefully dissected between semimembranosus and biceps femoris muscles. Vascular cross-clamps were placed above the proximal PAA on the distal superficial femoral artery (DSFA) and below on the popliteal artery between PA1 and PA2 segments. The aneurysm was removed, and surgical revascularisation with end-to-end anastomosis to the DSFA and proximal PA was performed with a $7 \mathrm{~mm}$ polyethylene-terephthalate vascular prosthesis. The patient was discharged on the third postoperative day without any complications with patent vascular graft and palpable crural arteries. The patient remains with a patent prosthetic graft 4 months after the surgery without any ultrasonographic signs of stenosis.

Conclusion: Up-to-date, open surgical resection remains a gold standard in the treatment of PAA with superior long-term results over endovascular techniques. Nevertheless, new endovascular techniques are becoming more sophisticated, allowing us to use these endovascular modalities as an alternative treatment option in selected patients.
\end{abstract}

Address: MUDr. Robert Novotný, Transplantation Surgery Department, Institute for Clinical and Experimental Medicine, Vídeňská 1958/9, 14021 Prague 4, e-mail: novr@ikem.cz

DOI: 10.1016/j.crvasa.2018.03.001 


\section{Introduction}

The most frequent site for true peripheral artery aneurysm formation is the popliteal artery (PA). ${ }^{1}$ However, it is still challenging to determine true popliteal artery aneurysm (PAA) prevalence in general population. Due to the improvements in diagnostic modalities and an ageing population, its prevalence seems to be on the rise. ${ }^{2}$ The prevalence of PAA based on a screening study is estimated to be approximately $1 \%{ }^{3}$ However, Tuveson et al. had shown that its prevalence seems to be even greater in patients with abdominal aortic aneurysm. ${ }^{4}$ The defining size of classifying PA as a PAA differs among authors. Some authors define PAA as a diameter of PA exceeding 0.7 $\mathrm{cm}$, while others report threshold value of $2 \mathrm{~cm}$, or $150 \%$ of the normal artery diameter. ${ }^{1,5}$ The clinical presentation of PAA ranges from the finding of an asymptomatic pulsatile popliteal mass on routine physical examination to acute limb-threatening ischaemia. It is strongly believed that the probability of thromboembolic complications is directly proportional to the size of the PAA. ${ }^{6}$ The incidence of rupture of PAA is estimated to be around $2 \%{ }^{7}$ Up-to-date, open surgical resection remains a gold standard in the treatment of PAA with outstanding long-term results. Nevertheless, new endovascular techniques such as Viabahn stent graft or highly flexible PTFE lined nitinol stents are becoming more sophisticated. ${ }^{8}$ This allows us to use these endovascular modalities as an alternative treatment option with improving results.., 10

\section{Case presentation}

A 71-year-old male patient with 100 m claudication interval on the lower left extremity was advised to our department for clinical examination and evaluation. The patient's medical history and medical background revealed: arterial hypertension (WHO Stage I), ischaemic heart disease (non-ST myocardial infarction vs vasospasm without the need of endovascular or surgical intervention managed by pharmacotherapy in August of 2000), and benign prostate hyperplasia. The patient's pharmacotherapy at the time was acetylsalicylic acid, ACl-inhibitor, alpha blocker, and a statin.

During a clinical examination, a pulsating circular resistance approximately $4 \mathrm{~cm}$ in diameter was palpated in the left popliteal fossa. CTAG was performed and revealed an occluded aneurysm of the proximal PA. The aneurysm dimensions were $4.6 \times 4 \times 5.4 \mathrm{~cm}$ (Figs.1. and 2). The crural arteries showed no signs of micro-embolisations from the aneurysm. Based on a CTAG finding the patient was indicated for surgical resection of the PAA.

The surgical procedure was performed under general anaesthesia. A posterior approach was used for the dissection of the aneurysm. After the incision was made, the aneurysm was carefully dissected between semimembranosus and biceps femoris muscles (Fig. 3). Popliteal vein and tibial nerve were carefully dissected and secured to prevent their damage during aneurysm resection. After the aneurysm dissection was complete, 10,000 units of heparin were administered to the patient. Vascular cross-clamps were placed above the PAA on the DSFA

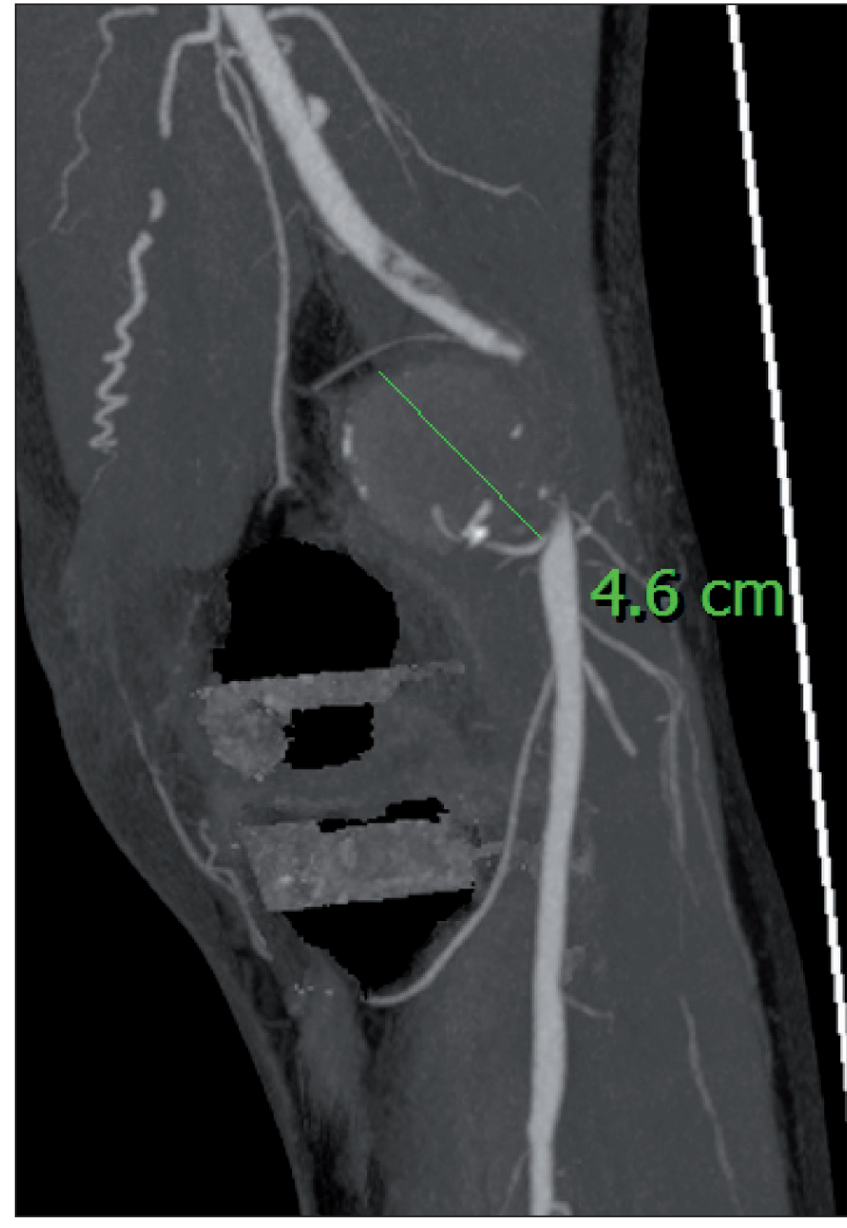

Fig. 1 - CTAG of the left popliteal fossa with occluded proximal popliteal artery and popliteal artery aneurysm (longitudinal section)

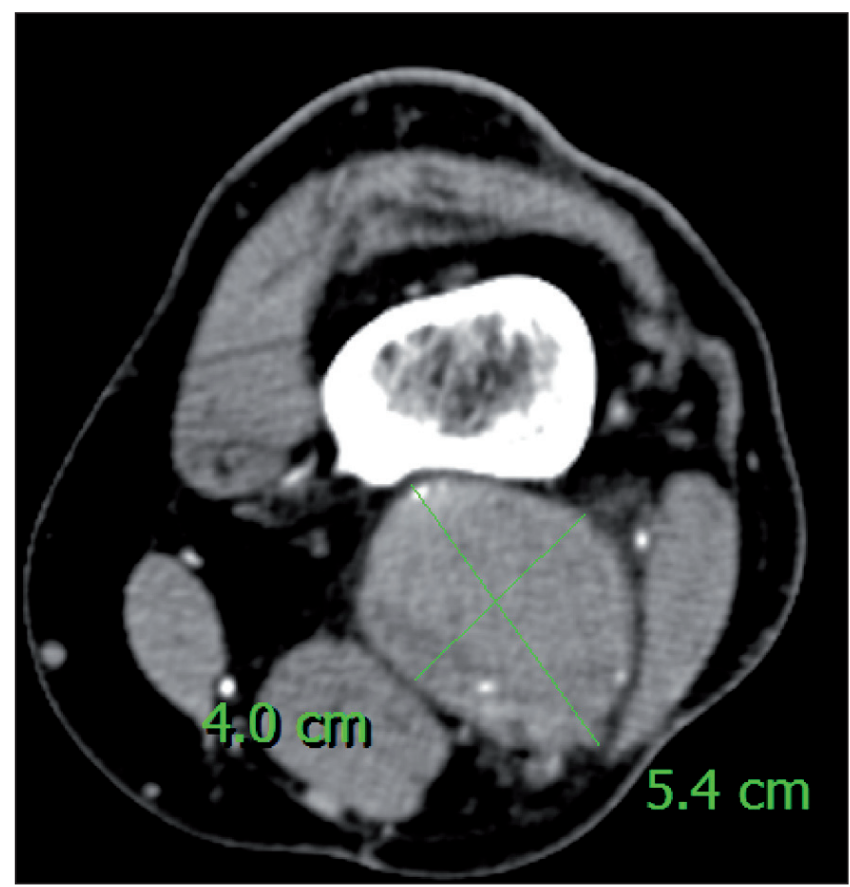

Fig. 2 - CTAG of the left popliteal fossa with occluded proximal popliteal artery aneurysm (transverse section) 
and below on the popliteal artery (PA1-PA2 border). The aneurysm was removed, and surgical revascularisation with end-to-end anastomosis to the DSFA and proximal PA was performed with $7 \mathrm{~mm}$ Gelsoft vascular prosthesis (Vacutek, Vascutek Terumo Group, Scotland). Afterwards, a protamine sulphate (protamine sulphate to heparin ration $1: 1)$ was administered to the patient, and the wound was closed in anatomical layers. The patient was discharged on the third postoperative day without any complications with palpable crural arteries. The patient remains with patent prosthetic graft 4 months after the surgery without any ultrasonographic signs of stenosis.

\section{Discussion}

Three distinct medical conditions affecting PA share similar clinical symptomatology: cystic adventitial disease, PA entrapment syndrome, PA aneurysm. ${ }^{11}$ It is essential to recognise and differentiate between these conditions as PAA is the prevailing cause of non-traumatic amputation of the lower limb. ${ }^{12}$ PAAs are bilateral in $50-70 \%$ of cases and are predominantly affecting males in the sixth and seventh decennium of their life. ${ }^{1}$ The incidence of rupture of PAA is estimated to be around $2 \% .^{7}$

Up-to-date, the gold standard in the treatment of PAA has been surgical resection of the aneurysm and bypass grafting using either prosthesis graft or autologous vein. ${ }^{10}$ It has been clearly established that aggressive approach

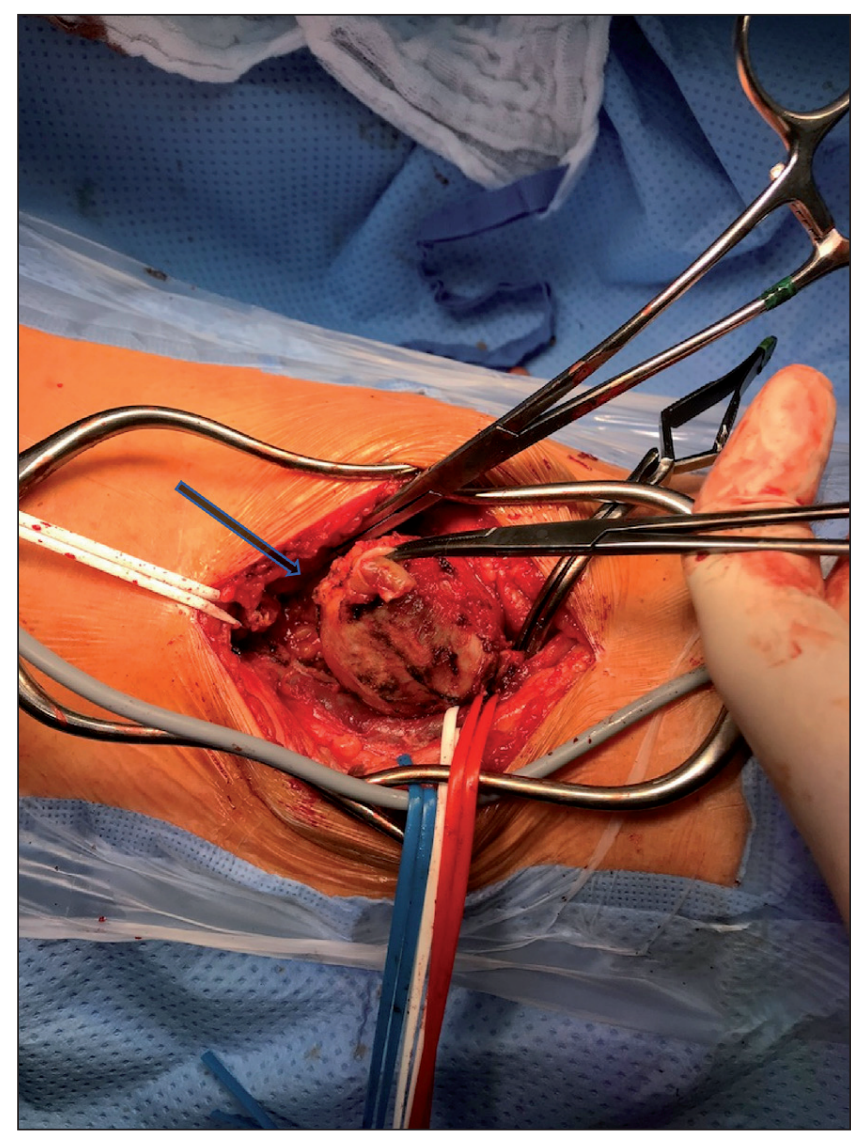

Fig. 3 - Resected left proximal popliteal artery aneurysm (arrow: AP2 segment) to cardiovascular risk reduction (blood pressure control, dietary adjustments and smoking abstinence, antiplatelet treatment, normal blood glycaemia) can prolong grafts' patency and improves patients' survival. ${ }^{13}$

An alternative treatment option for PAA is the use of endovascular devices. A study by Cervin et al. had demonstrated inferior results of endovascular devices when compared to open repair. The endovascular devices had shown lower patency at three months and one year when compared to open repair. ${ }^{14}$ This was attributed to the stresses caused by the knee movement as was clearly demonstrated by Möllenhoff et al. work on the Viabahn covered stent graft. ${ }^{15}$ Golchehr et al. showed in their meta-analysis that complications associated with endovascular devices such as stent fractures are occurring in almost one third of devices used in the popliteal region. ${ }^{16}$ Despite the unknown durability and lower patency of endovascular devices, in high-risk patients, this treatment option is a beneficial and safe treatment modality. ${ }^{17}$

In conclusion, an open repair of PAA with bypass grafting shows better long-term results regarding the patency and lower incidence of complications than endovascular repair. ${ }^{16}$ Thus, open surgical treatment of PAA remains still the gold standard. But the ever-evolving endovascular devices like Viabahn stent graft or highly flexible PTFE lined nitinol stents are becoming more and more sophisticated. ${ }^{8}$ Therefore, these devices are becoming a strong competitor for traditional open repair of PAA and should be considered as an alternative treatment modality for selected groups of patients.

\section{Conclusion}

Endovascular repair of PAA is an attractive alternative to a standardised open repair. The question regarding the durability and long-term results of endovascular devices is still not fully answered as these devices are becoming more and more sophisticated. Up-to-date an open surgical repair of PAA with bypass grafting shows better long-term results regarding the patency and lower incidence of complications than endovascular repair. However, in high-risk patients, the use of endovascular techniques seems to be a feasible and safe treatment option.

\section{Conflict of interest}

The authors declare that there is no conflict of interest regarding the publication of this article.

\section{Funding body}

This research received no specific grant from any funding agency in the public, commercial, or not-for-profit sectors.

\section{Ethical statement}

Authors state that the research was conducted according to ethical standards.

\section{Informed consent}

Written informed consent was obtained from the patient for publication of this case report and accompanying images. A copy of the written consent is available for review by the Editor-in-Chief of this journal. 


\section{Acknowledgements}

The author would like to thank to doc. MUDr. Jiri Fronek, PhD, FRCS, Transplantation Surgery Department, Institute for Clinical and Experimental Medicine, Prague, Czech Republic and MUDr. Kvetoslav Lipar, Transplantation Surgery Department, Institute for Clinical and Experimental Medicine for providing their opinion on this case.

\section{References}

1. Gallala S, Verbist J, Van Den Eynde W, Peeters P. Popliteal artery aneurysm: when open, when endo? J Cardiovasc Surg (Torino) 2014;55(2 Suppl 1):239-247.

2. Appleton ND, Davies L, Lewis MH. Risk of new aneurysms after surgery for popliteal artery aneurysm (Br J Surg 2008;95:571575). Br J Surg. 2008;95(9):1185; author reply 1185.

3. Trickett JP, Scott RA, Tilney HS. Screening and management of asymptomatic popliteal aneurysms. J Med Screen 2002;9:92-93.

4. Tuveson V, Löfdahl HE, Hultgren R. Patients with abdominal aortic aneurysm have a high prevalence of popliteal artery aneurysms. Vasc Med 2016;21:369-375.

5. Wright LB, Matchett WJ, Cruz CP, et al. Popliteal artery disease: diagnosis and treatment. Radiographics 2004;24:467-479.

6. Pasternak J, Nikolić D, Vučaj Ćirilović V, Popović V. Symptomatic popliteal artery aneurysms as limb-threatening disease. Ital J Vasc Endovasc Surg 2015;22:197-201.

7. Brown SL, Lewis M, Morrow DR. Endovascular Repair of Ruptured Popliteal Artery Aneurysms: A Case Report and Review of the Literature. EJVES Short Rep 2016;32:24-28.

8. Saxon RR, Chervu A, Jones PA, et al. Heparin-bonded, expanded polytetrafluoroethylene-lined stent graft in the treatment of femoropopliteal artery disease: 1-year results of the VIPER (Viabahn Endoprosthesis with Heparin Bioactive
Surface in the Treatment of Superficial Femoral Artery Obstructive Disease) trial. J Vasc Interv Radiol 2013;24:165173; quiz 174.

9. Pulli R, Dorigo W, Castelli P, et al. A multicentric experience with open surgical repair and endovascular exclusion of popliteal artery. Eur J Vasc Endovasc Surg 2013;45:357-363.

10. Björck M, Beiles B, Menyhei G, et al. Editor's Choice: Contemporary treatment of popliteal artery aneurysm in eight countries: A Report from the Vascunet collaboration of registries. Eur J Vasc Endovasc Surg 2014;47:164-171.

11. Jarraya M, Simmons S, Farber A, et al. Uncommon diseases of the popliteal artery: a pictorial review. Insights Imaging 2016;7:679-688.

12. Coelho A, Lobo M, Martins V, et al. Serratia liquefaciens Infection of a Previously Excluded Popliteal Artery Aneurysm. EJVES Short Rep 2016;34:1-4.

13. Dattani N, Ali M, Aber A, et al. Cardiovascular Risk Reduction is Important for Improving Patient and Graft Survival After Ligation and Bypass Surgery for Popliteal Artery Aneurysm. Vasc Endovascular Surg 2017;51:261-268.

14. Cervin A, Tjärnström J, Ravn $\mathrm{H}$, et al. Treatment of Popliteal Aneurysm by Open and Endovascular Surgery: A Contemporary Study of 592 Procedures in Sweden. Eur J Vasc Endovasc Surg 2015;50:342-350.

15. Möllenhoff C, Katsargyris A, Steinbauer M, et al. Current status of Hemobahn/Viabahn endografts for treatment of popliteal aneurysms. J Cardiovasc Surg (Torino) 2013;54:785791.

16. Golchehr B, Zeebregts CJ, Reijnen MMPJ, Tielliu IFJ. Long-term outcome of endovascular popliteal artery aneurysm repair. J Vasc Surg 2018;67:1797-1804.

17. Ardita V, Giaquinta A, Orrico M, et al. Endovascular treatment of chronic occluded popliteal artery aneurysm: early and mid-term outcomes. J Cardiovasc Surg (Torino) 2018;59:405-411. 